ISSN : 1978-4333, Vol. 03, No. 02

\title{
Struktur Nafkah Rumahtangga Petani Transmigran : Studi Sosio-Ekonomi di Tiga Kampung di Distrik Masni Kabupaten Manokwari $^{1}$
}

\author{
Paulina P. Tulak ${ }^{2}$, Arya Hadi Dharmawan ${ }^{3}$, dan Bambang Juanda ${ }^{4}$
}

\begin{abstract}
Among the primary objectives of transmigration program are to increase the economic status of transmigrant farm-households and enhancing rural infrastructures of the local region. To see wether such objective is attainable, a study of transmigrant farm households has been conducted in West Papua. The study attempts: (1) to know whether there is any relation between the socio-cultural/ethnical background of the transmigrant farm-household with the achievement of welfare status, (2) to analyze factors influencing to the income level of transmigrant farm-households, and (3) to understand how the farm households enhance the degree of economic status by building numerous livelihood strategies. The methods as used in the analysis are: (1) income level analysis of the households, (2) gini-ratio analysis, and (3) descriptive analysis. The results of this study are: socio-cultural (ethnical) setting of transmigrant has a substantial influence to the achievement of welfare level. Javanese transmigrant showed a much higher income achievement due to their strong engagement in the non-farm economy, as compared to Papuanese transmigrant farm-households. The nonfarm economy provides a strong basis for economic growth at household level. However, the growth of non-farm economy unexpectedly caused an increasing tendency of income disparity among different farm household strata. Since non-farm economy shares a positive contribution for regional economic growth, the study concludes, that the government needs to take seriously this economic sector into account when regional development needs to be well-accomplished in West Papua.
\end{abstract}

Keywords: Welfare status, livelihood structure, farm-household, income structure, livelihood strategies, sosio-economic setting.

\section{PENDAHULUAN}

Pembangunan pedesaan adalah istilah yang dipakai untuk menjelaskan keseluruhan proses perubahan terencana yang dilakukan terhadap masyarakat desa. Dalam banyak hal, pembangunan pedesaan didorong untuk lebih memanfaatkan inisiatif dan kekuatan-kekuatan lokal dalam upaya meningkatkan produksi dan taraf hidup

${ }^{1}$ Bagian dari Tesis, disampaikan sebagai makalah pada Seminar Sekolah Pascasarjana IPB, 2009

${ }^{2}$ Mahasiswa S2 Program Studi Pengembangan Wilayah Pedesaan Pascasarjana IPB

${ }^{3}$ Ketua Komisi Pembimbing

${ }^{4}$ Anggota Komisi Pembimbing 
ekonomi yang lebih baik. Beranjak dari prinsip tersebut, pembangunan pedesaan di suatu kawasan harus menyesuaikan diri pada setting sosial, ekonomi dan ekologi setempat. Dengan berbasiskan pada sumberdaya lokal, pembangunan pedesaan sering ditekankan pada pencapaian bidang ekonomi, sebab pada sisi inilah desa berada pada kondisi yang memprihatinkan. Menurut Mizra (1982), pembangunan merupakan suatu usaha manusia melalui usaha-usaha yang terpadu dan terencana yang menyatukan seluruh sistem pengetahuan baik fisik, biologi sosial, ekonomi, maupun ilmu tentang hubungan antar-manusia.

Program transmigrasi yang dijalankan oleh pemerintah sejak masa orde baru hingga saat ini, pada hakekatnya merupakan bagian dari pendekatan integral pembangunan nasional yang ditujukan untuk mempercepat pertumbuhan kawasan terutama yang masih terisolir atau tertinggal dengan orientasi pada peningkatan kesejahteraan. Orientasi ini sangat jelas ditegaskan dalam Undang-Undang nomor 15 tahun 1997 tentang Ketransmigrasian, serta pada Peraturan Pemerintah nomor 2 tahun 1999 tentang Penyelenggaraan Transmigrasi.

Program transmigrasi merupakan bertujuan untuk meningkatkan taraf hidup ekonomi rumahtangga lapisan bawah yang menghadapi persoalan kemiskinan karena kelangkaan lahan dan tekanan ekonomi di daerah asal. Di dalam program transmigrasi, kepada setiap kepala keluarga (KK) diberikan lahan cuma-cuma seluas 2,5 hektar, jaminan hidup selama waktu tertentu dan berbagai bantuan teknis seperti kredit, sarana produksi, penyuluhan dan sebagainya. Sejalan dengan prinsip tersebut, penempatan transmigrasi di Kabupaten Manokwari pun diorientasikan untuk mengentaskan kemiskinan. Dalam implementasinya, dijumpai berbagai dampak yang tidak pernah diduga sebelumnya. Di satu sisi, aktivitas pertanian yang dijalankan di tanah-tanah subur dan sawah baru menghasilkan peningkatan derajat kesejahteraan dan pembukaan daerah terisolasi. Di sisi lain, exposure kawasan yang cukup tinggi dengan pengaruh luar, telah mengakibatkan beberapa perubahan sosial yang berarti dan tidak pernah diantisipasi. Pengalaman yang dipetik dari Manokwari tidaklah khas dan berlaku di daerah itu saja. Di berbagai kawasan transmigrasi selain didapati pertumbuhan ekonomi yang cepat, terjadi pula perubahan dari sisi tatapemukiman, keramaian, berkembangnya pusat-pusat pemerintahan baru, hingga berkembangnya relasi-relasi sosial baru.

Secara kesejarahan, program transmigrasi telah dilaksanakan sejak zaman kolonial Belanda dengan apa yang disebut sebagai kolonisasi dari penduduk yang dipindahkan dari Bagelen Keresidenan Kedu yang ditempatkan di Gedong Tataan Lampung pada tahun 1905 (Ramadhan et. al., 1993). Program ini kemudian diteruskan oleh pemerintah Indonesia mengingat adanya ketimpangan persebaran penduduk terutama antar pulau Jawa dan pulau non Jawa. Sejak saat itu, tujuan program transmigrasi bukan hanya semata-mata geografis, namun berubah menjadi program pembangunan wilayah dan menjadi salah satu program integrasi nasional (Utomo, 2005). Dengan memperhatikan sisi kesejarahan, maka sesungguhnya proses perubahan ekonomi dan sosio-budaya akibat program transmigrasi di kawasan setempat sudah dapat diperkirakan sebelumnya.

Menurut Khairuddin (1992), terdapat persoalan lain berupa perbedaan sosial-budaya antara transmigran dan penduduk lokal di daerah tujuan transmigrasi. Perbedaan karakter sosio-budaya ini merupakan salah satu titik krusial yang dihadapi dalam 
rangka pengembangan masyarakat di desa-desa transmigran. Selain itu faktor-faktor seperti kondisi fisik, iklim, infrastruktur irigasi, kondisi tanah, kondisi sumberdaya alam, sumberdaya manusia, motivasi-dan-etika kerja, serta struktur penguasaan lahan, ikut mempengaruhi dinamika perkembangan kawasan transmigrasi. Sedangkan kondisi non fisik seperti aspek sosio-budaya (adat istiadat, kebiasaankebiasaan yang hidup dalam masyarakat yang masih ditaati, gotong royong), politik (pola kepemimpinan dan keamanan desa) dan religi (pembentukan sikap mental) menjadi konteks yang mewarnai ke arah mana kawasan transmigrasi akan berkembang.

Didasarkan pada latar belakang di atas, studi ini hendak melihat secara lebih mendalam dimensi sosio-budaya dari program transmigrasi. Dengan mengambil setting kawasan transmigrasi di Manokwari, hendak diperbandingkan seberapa jauh perkembangan sosio-ekonomi yang dialami oleh kawasan transmigrasi pada dua kelompok etnis yang berbeda (Jawa dan Papua).

\section{PERUMUSAN MASALAH}

Kabupaten Manokwari merupakan salah satu kabupaten di Provinsi Papua Barat yang banyak menerima program transmigrasi nasional. Daerah asal transmigrasi di Manokwari terutama dari provinsi-provinsi DKI Jakarta, Jawa Barat, Jawa Tengah, DIY, Jawa Timur, Bali, NTB dan NTT. Sejarah penempatan transmigrasi di kawasan ini dimulai sejak masa "pra-pelita" yaitu tahun 1964. Secara akumulatif, realisasi penempatan transmigran nasional di Kabupaten Manokwari sejak masa "pra-pelita" di tahun 1964 sampai dengan tahun 1997 adalah 9.660 KK (41.170 jiwa). Penempatan transmigran di Kabupaten Manokwari dari masa ke masa dapat dilihat pada Tabel 1 di bawah ini.

Tabel 1. Penempatan Transmigran di Kabupaten Manokwari, 1964-1997

\begin{tabular}{|l|r|}
\hline \multicolumn{1}{|c|}{ Tahun } & \multicolumn{2}{|c|}{ Jumlah Transmigran yang Ditempatkan } \\
(Jiwa)
\end{tabular}

Sumber : Berbagai data sekunder, 2007

Salah satu kawasan transmigran di Manokwari adalah Distrik (atau kecamatan) Masni. Kawasan ini secara administrasi merupakan distrik yang berada di Wilayah Kabupaten Manokwari, memiliki luas wilayah 1.406,10 $\mathrm{Km}^{2}$ dan terdiri dari 32 kampung (desa). Distrik Masni, mulai ditempati oleh 3.299 KK atau 15.194 Jiwa transmigran nasional mulai tahun 1983 sampai dengan tahun 1991. Berdasarkan hasil sensus yang dilakukan di Distrik Masni pada tahun 2006, jumlah penduduk secara keseluruhan menjadi 12. 484 Jiwa terdiri dari Laki-laki 6.647 Jiwa dan Perempuan 5.837 Jiwa (BPS Manokwari, 2007). Hal ini menunjukkan bahwa terjadi adanya pengurangan jumlah jiwa di Distrik Masni yang disebabkan oleh adanya 
pergerakan penduduk dari transmigran yang meninggalkan lokasi transmigrasi dikarenakan kondisi lahan yang kurang subur, minimnya pengalaman di bidang pertanian, serta sulitnya beradaptasi dengan lingkungan yang baru.

Priyono (2004), menyatakan bahwa pengembangan wilayah transmigrasi merupakan usaha menumbuh-kembangkan wilayah yang memiliki potensi sumberdaya alam dengan keunggulan komoditas tertentu yang dikelolah secara terpadu dengan mengisi kekurangan kualitas dan kuantitas sumberdaya manusia melalui program transmigrasi. Meski demikian, proses adaptasi yang berat seringkali memupuskan harapan peningkatan status ekonomi para transmigran. Seringkali, kata kuncinya terletak pada ketahanan para transmigran dalam membangun sistem penghidupan (livelihood system) dalam kondisi yang serba baru tersebut.

Mardiyaningsih (2003) menunjukkan bahwa mereka yang memiliki keunggulan dalam pencapaian tingkat ekonomi, biasanya memiliki kelenturan dalam menyusun strategi bertahan hidup (livelihood strategies). Hal ini menunjukkan bahwa mereka yang memiliki kelenturan dalam struktur nafkah (livelihood structure) akan menunjukkan tingkat stabilitas ekonomi rumahtangga yang lebih baik. Pada kenyataannya, mereka dari lapisan ekonomi menengah ke atas akan menunjukkan kinerja yang lebih baik dalam bernafkah. Dengan menerapkan berbagai strategi nafkah (livelihood diversity) bertumpu pada sumberdaya yang mereka miliki, rumahtangga- pertanian berhasil meningkatkan derajat kesejahteraannya (Dharmawan, 2001). Penelitian Mardiyaningsih (2003) juga menunjukkan bahwa faktor kesejahteraan sosial ekonomi dan kelimpahan modal (available resources) yang dimiliki oleh masing-masing rumahtangga akan menentukan strategi nafkah yang dipilih ke depan.

Strategi nafkah (livelihood strategies) dalam hal ini dibatasi sebagai keseluruhan cara atau kegiatan ekonomi yang diambil oleh anggota rumahtangga sekedar untuk bertahan hidup (survival) dan/atau (dalamkondisi memungkinkan) untuk membuat status kehidupan menjadi lebih baik melalui pemanfaatan berbagai sumberdaya yang dimiliki. Scoones (1998), menggolongkan strategi nafkah petani setidaknya menjadi tiga golongan besar. Ketiga strategi tersebut adalah: (1) rekayasa sumber nafkah pertanian, yang merupakan usaha pemanfaatan sektor pertanian agar lebih efektif dan efisien, baik melalui penambahan input eksternal berupa tenaga kerja atau teknologi (intensifikasi) maupun dengan memperluas lahan garapan pertanian (ekstensifikasi); (2) pola nafkah ganda yang merupakan usaha yang dilakukan dengan cara mencari pekerjaan selain sektor pertanian untuk menambah pendapatan (diversifikasi nafkah); (3) rekayasa spasial merupakan usaha yang dilakukan dengan cara mobilisasi/perpindahan penduduk baik secara permanen maupun sirkular (migrasi) dalam rangka mencari sumber nafkah (livelihood sources) baru di tempat lain. Persoalannya, tidak setiap rumahtangga mampu merespons dengan baik atas segala sesuatu (sumberdaya maupun kendala bernafkah) yang ada di hadapannya. Sebagian rumahtangga bahkan gagal mengembangkan kehidupan sosio-ekonominya dan jatuh ke lembah kemiskinan kembali. Dengan demikian, ada persoalan proses adaptasi yang seringkali tidak berhasil dijalani.

Dalam hal program transmigrasi pun sebenarnya, pemerintah telah mengantisipasi persoalan-persoalan tersebut sejak dini. Setiap warga transmigran akan mendapatkan fasilitas yang sama dalam mengembangkan usaha pertanian mereka demi 
memperoleh tingkat kesejahteraan yang optimum. Namun fakta yang terjadi, tingkat kesejahteraan yang dicapai setiap rumahtangga berbeda-beda dilihat dari pendapatannya. Strategi nafkah (livelihood strategies) yang dibangun oleh rumahtangga transmigran pun berbeda-beda tergantung bagaimana daya adaptasi mereka terhadap sistem ekologi setempat. Berbagai laporan menunjukkan adanya transmigran yang terpaksa kembali ke daerah asal, karena gagal membangun ekonomi yang lebih baik. Pada jenis pekerjaan yang mereka tekuni, diperoleh fakta bahwa terdapat banyaknya transmigran yang mencari nafkah benar-benar di luar sektor pertanian, dikarenakan kegagalan mereka beradaptasi dengan kawasan lokal. Di daerah tujuan, banyak ditemukan transmigran yang sistem nafkahnya justru lebih banyak didukung oleh pekerjaan luar pertanian (non-farm economy).

Penelitian terdahulu menunjukkan bahwa, strategi nafkah sangat terkait dengan karakter dan setting sosio-eco-budaya yang membentuk etika-moral para transmigran. Transmigran dengan setting ekologi penuh tantangan, biasanya menghasilkan orang-orang yang tangguh dalam menghadapi tantangan. Sementara mereka yang biasa dimanjakan oleh kelimpahan sumberdaya alam, cenderung kurang termotivasi untuk bertahan. Hal ini sebagaimana terlihat pada penelitian tentang rumahtanga pedesaan yang menghadapi kerasnya kehidupan desa dan terpaksa bermigrasi ke kota untuk mencari nafkah di tengah persaingan yang keras perkotaan (Suwartika, 2003).

Dalam hal ini Dharmawan (2007) menegaskan bahwa strategi penghidupan (livelihood strategies) pedesaan adalah: "strategi penghidupan dan nafkah yang dibangun dan selalu menunjuk pada peran sektor pertanian. Dalam posisi sistem nafkah yang demikian, basis nafkah rumahtangga petani adalah segala aktivitas ekonomi pertanian dan ekonomi non-pertanian yang terkait dengannya. Karakteristik sistem nafkah penghidupan dan nafkah yang dicirikan oleh bekerjanya dua sektor ekonomi, juga sangat ditentukan oleh sistem sosial budaya setempat. Terdapat tiga elemen sosial terpenting yang sangat menentukan bentuk strategi nafkah yang dibangun oleh petani kecil dan rumahtangganya yaitu (1) infrastruktur sosial (setting kelembagaan dan tatanan norma sosial yang berlaku), (2) struktur sosial (setting lapisan sosial, struktur agraria, struktur demografi, pola hubungan pemanfaatan ekosistem lokal, pengetahuan lokal), (3) supra-struktur sosial (setting ideologi, etikamoral ekonomi, dan sistem nilai yang berlaku)". Dari pemahaman ini, dapat dijelaskan bahwa daya kebertahan hidup (survival capacity) atau keberhasilan para transmigran dalam melanjutkan kehidupan dan membangun sistem penghidupannya, sangat dipengaruhi oleh banyak faktor.

Berdasarkan persoalan-persoalan tersebut di atas, beberapa pertanyaan penelitian yang hendak dijawab dan sekaligus menjadi tujuan dalam studi ini dirumuskan sebagai berikut :

1. Adakah hubungan yang nyata antara latar belakang sosio-budaya (ciri etnisitas) rumahtangga petani transmigran dengan pencapaian tingkat kesejahteraannya, yang dilihat dari tingkat pendapatan dan strategi nafkahnya.

2. Bagaimana arah pengembangan ekonomi kawasan dengan memperhatikan struktur dan strategi nafkah rumahtangga petani (dari ciri etnis yang berbeda) di Papua Barat. 
Beberapa asumsi dasar yang melandasi pertanyaan penelitian di atas, adalah premis yang mengatakan bahwa latar belakang sosio-budaya sangat menentukan bentuk etika-moral ekonomi seseorang. Dengan kekhasan etikal ini, maka pilihan strategi bernafkah yang ditampilkan oleh setiap etnis juga akan berbeda. Pilihan strategi nafkah selanjutnya akan menentukan struktur dan derajat status ekonomi rumahtangga pada masing-masing rumahtangga dari etnis yang berbeda-beda.

\section{METODOLOGI PENELITIAN}

Penelitian ini dilakukan di tiga kampung atau desa (kampung pertama adalah Sumberboga yang mewakili kawasan transmigrasi umum, kampung kedua adalah Meiforgah yang mewakili transmigrasi lokal dan kampung ketiga adalah Sembab mewakili komunitas asli papua, sebagai kontrol). Ketiga kampung terletak di Distrik (kecamatan) Masni Kabupaten Manokwari Provinsi Papua Barat. Penelitian dimulai pada bulan Agustus 2008 sampai dengan November 2008.

Unit analisis penelitian adalah rumahtangga. Pemilihan kampung untuk diteliti ditentukan secara sengaja (purposive), agar dapat memenuhi tujuan penelitian yang telah dipaparkan dimuka. Data diambil dalam penelitian ini meliputi data primer maupun data sekunder. Data sekunder dikumpulkan dari berbagai instansi terkait Data primer diperoleh dari rumahtangga contoh melalui metode wawancara dan wawancara-mendalam terhadap responden dengan menggunakan kuesioner sebagai panduan.

Rumahtangga contoh diambil secara acak-terstratifikasi dan bertahap (multistage stratified sampling) di masing-masing kampung. Setiap kampung diambil sebanyak 15 rumahtangga contoh, sehingga total respoden 45 rumahtangga. Data rumahtangga meliputi: (1) struktur rumahtangga, (2) struktur asset rumahtangga, (3) struktur pendapatan rumahtangga, (4) struktur pengeluaran rumahtangga, dan (5) bentuk dan kapasitas pemupukan modal (saving capacity).

Penelitian ini menggunakan pendekatan gabungan kuantitatif, kualitatif, dan deskriptif. Data pendapatan dan pengeluaran akan divaluasi dalam satuan rupiah per tahun. Tingkat kesejahteraan direpresentasikan dengan ukuran rata-rata pendapatan rumahtangga per tahun dari rumahtangga contoh. Pendapatan total rumahtangga adalah jumlah dari pendapatan dari berbagai sektor ekonomi, yang dinyatakan sebagai:

Total pendapatan rumahtangga $=\sum P_{i}+\sum N p_{i}$ dimana :

$\mathrm{P}_{\mathrm{i}} \quad=$ Pendapatan dari usaha di sektor pertanian ke-i, dimana $\mathrm{i}=1,2,3 \ldots$

$\mathrm{NP}_{\mathrm{i}}=$ Pendapatan dari usaha di luar sektor pertanian ke-i, dimana $\mathrm{i}=$ $1,2,3 \ldots$

Analisis dekomposisi koefisien Gini (decomposition analysis of the Gini coefficient) yang berkisar antara 0 (distribusi pendapatan sangat merata) sampai 1 (ketimpangan pendapatan sangat tinggi) diterapkan dalam pengukuran formula ketimpangan. Metode dekomposisi Gini sangat umum diterapkan dalam analisa ekonomi (Alderman dan Garcia,1993). Dalam penelitian ini formula dekomposisi Gini Ratio dikembangkan dengan persamaan sebagai berikut : 


$$
\begin{aligned}
G(Y)=\sum \text { si } & R(Y, Y i) G(Y i) \\
\text { dimana: } \mathrm{G}(\mathrm{Y}) & =\text { Gini rasio pendapatan total } \\
\mathrm{Yi} & =\text { Pendapatan dari sumber pendapatan ke } \mathrm{i} \\
\mathrm{si} & =\text { Proporsi sumber pendapatan ke } \mathrm{i} \\
\mathrm{R}(\mathrm{Y}, \mathrm{Yi}) & =\text { Rasio korelasi ranking } \\
\mathrm{G}(\mathrm{Yi}) & =\text { Gini rasio dari sumber pendapatan ke } \mathrm{i}
\end{aligned}
$$

Analisis deskriptif dilakukan untuk variabel karakteristik responden seperti: umur, pendidikan, jumlah anggota keluarga, pendapatan, lama tinggal, tingkat kesejahteraan (pendapatan, konsumsi, kesehatan, kondisi perumahan dan fasilitas perumahan) dinyatakan dalam bentuk bilangan ordinal sedangkan mata pencaharian dinyatakan dalam skala bilangan nominal.

\section{STRUKTUR DAN TRANSFORMASI NAFKAH PEDESAAN}

Hasil studi menunjukkan dan menegaskan dugaan kuat adanya transformasi struktur nafkah yang berlangsung secara dramatis di kawasan studi. Fakta dari lapangan menunjukkan bahwa, peranan sektor pertanian di ketiga daerah penelitian tidak lagi signifikan, atau paling tidak, menurun kontribusinya dalam menunjang sistem ekonomi rumahtangga petani transmigran secara keseluruhan. Tabel 2 dan Gambar 1 menegaskan bahwa karena respons terhadap berbagai kecenderungan eksternal, struktur ekonomi rumahtangga petani transmigran di tiga kampung penelitian mengalami perubahan di luar dugaan semua pihak, termasuk mereka yang mendisain program transmigrasi pada awalnya.

Perubahan transformasional tersebut berkenaan dengan struktur nafkah rumahtangga petani (di lokasi penelitian) yang tidak lagi hanya mengandalkan pada single-source of income (farm). Proposisi yang dipegang untuk melihat struktur nafkah selama ini menegaskan bahwa komposisi terbesar dari sistem nafkah rumahtangga petani di pedesaan, seharusnya disumbang dari sektor pertanian. Namun dari penelitian ini tampak bahwa, keyakinan bahwa sektor pertanian sebagai penyumbang terbesar struktur nafkah rumahtangga petani tidak dapat dipertahankan lagi. Hampir semua rumahtangga petani transmigran (sekalipun intensitasnya berbeda-beda tergantung latar belakang etnisitasnya) kini tidak lagi hanya menggantungkan diri pada sektor ekonomi tunggal yaitu pertanian (farm) saja, melainkan juga pada sektor nonpertanian (non-farm) serta sedikit bantuan pemerintah. Implikasi lebih lanjut dari pernyataan tersebut adalah, bahwa pertanian kini tidak dapat lagi dipandang sebagai instrumen tunggal bagi pengembangan wilayah setempat (sebagaimana keyakinan ini dipegang pada saat merumuskan tujuan program transmigrasi di masa awal).

Rumahtangga petani transmigran etnis Jawa yang berada di Sumberboga mengalami transformasi struktur nafkah yang lebih cepat dan lebih luas bila dibandingkan dengan rumahtangga petani transmigran etnis lokal di kedua kampung lainnya (Meiforgah dan Sembab, yang relatif masih berbasis pertanian). Dengan fakta ini, pertanyaan penelitian pertama yang mempertanyakan relasi antara etnisitas dan struktur nafkah terjawab. 
Tabel 2. Struktur Nafkah di Lokasi Penelitian, 2008

\begin{tabular}{|l|l|c|c|c|c|}
\hline \multirow{2}{*}{ No } & \multirow{2}{*}{ Kampung } & \multicolumn{2}{|c|}{ Tingkat Pendapatan (Rp/tahun) } & \multirow{2}{*}{ Total } \\
\cline { 3 - 5 } & & $\begin{array}{c}\text { Sektor } \\
\text { Farm }\end{array}$ & $\begin{array}{c}\text { Sektor Non- } \\
\text { Farm }\end{array}$ & Bantuan & \\
\hline 1 & Sumberboga & 6.100 .000 & 24.031 .800 & 746.667 & 30.878 .467 \\
& & $(19,75 \%)$ & $(\mathbf{7 7 , 8 3} \%)$ & $(2,42 \%)$ & $(100 \%)$ \\
\hline 2 & Meiforgah & 6.873 .333 & 5.298 .333 & 4.026 .667 & 16.198 .333 \\
& & $(\mathbf{4 2 , 4 3} \%)$ & $(\mathbf{3 2 , 7 1 \% )}$ & $\mathbf{( 2 4 , 8 6 \% )}$ & $(100 \%)$ \\
\hline 3 & Sembab & 7.209 .682 & 3.642 .667 & 5.801 .333 & 16.653 .681 \\
& & $\mathbf{( 4 3 , 2 9 \% )}$ & $\mathbf{( 2 1 , 8 8 \% )}$ & $\mathbf{( 3 4 , 8 3 \% )}$ & $(100 \%)$ \\
\hline
\end{tabular}

Sumber: data primer (diolah)

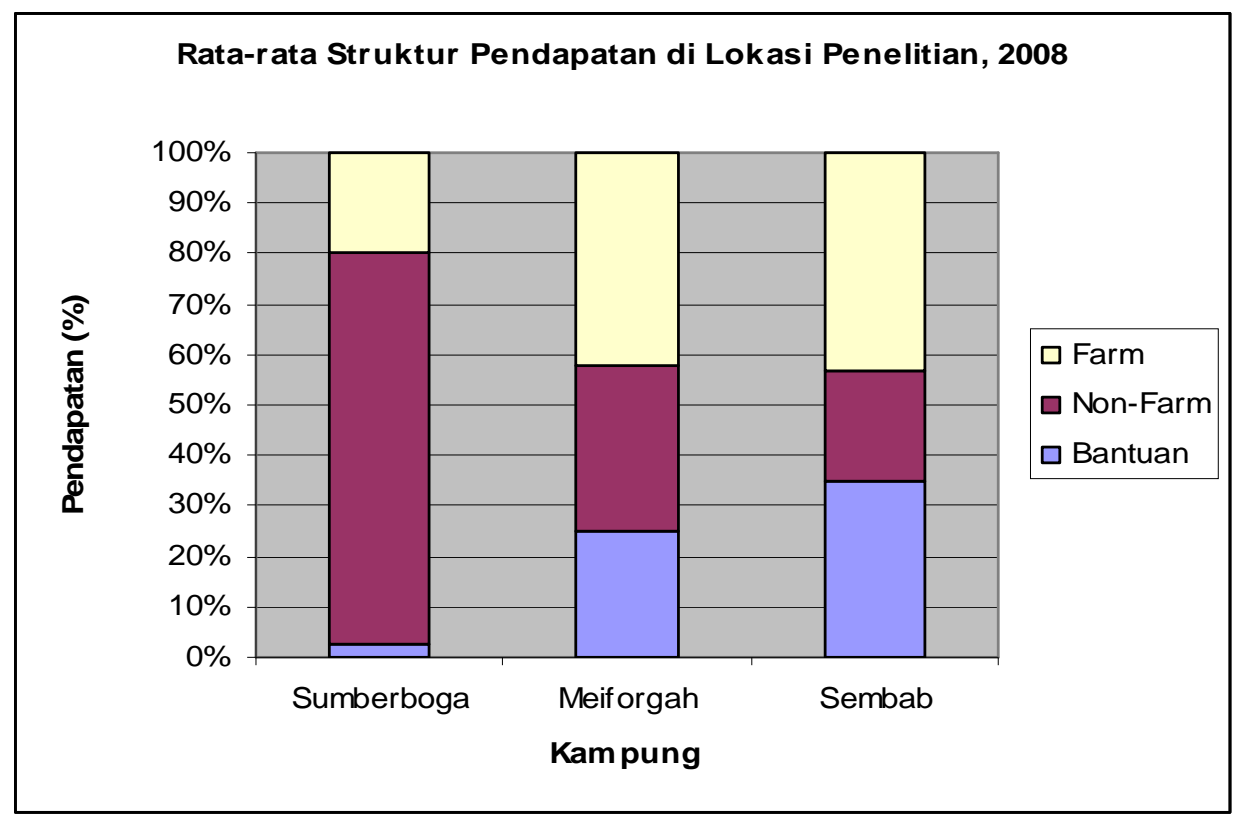

Sumber: data primer (diolah)

Gambar 1. Struktur Nafkah (Pendapatan) di Tiga Lokasi Penelitian, 2008

Secara mutlak, rata-rata pendapatan per tahun rumahtangga petani transmigran di Kampung Meiforgah maupun Sembab adalah Rp 16.198.467,- dan Rp 16.653.681,sehingga relatif sama. Sedangkan untuk Kampung Sumberboga rata-rata pendapatan rumahtangga petani per tahun adalah $\mathrm{Rp} 30.878 .467$,- jauh melebihi capaian dari kedua kampung lainnya, karena kontribusi pendapatan dari sektor non-farm yang signifikan.

\section{TIPE STRATEGI NAFKAH DAN DINAMIKANYA}

Dalam rangka bertahan hidup dan meningkatkan status sosial-ekonomi, setiap rumahtangga petani membangun mekanisme nafkah. Keseluruhan mekanisme bernafkah tersebut membentuk strategi nafkah (livelihood strategy) yang khas. Dari hasil pengamatan dapat diinventarisasi sejumlah strategi nafkah, sebagai berikut: 
1. "Pola/strategi nafkah berserak". Artinya, rumahtangga petani transmigran menggandakan pekerjaannya secara acak-berserakan ke segala sektor selain di sektor pertanian. Strategi ini dikembangkan tergantung ketersediaan waktu dan tenaga yang tersedia (Iqbal, 2004). misalnya menjadi buruh bangunan, buruh pabrik, tukang bangunan, membuka bengkel, warung sembako, warung makan, sopir angkutan umum, ojek dan sebagainya. Pola nafkah berserak terutama dilakukan di Kampung Sumberboga dapat dijelaskan sebagai berikut: (1) "serakan waktu", artinya bahwa waktu yang diperlukan dalam pencaharian nafkah tidak lagi bersifat konstan dan menentu, tetapi terkait dengan kesempatan dan peluang pada mata pencaharian lainnya, (2) "serakan spasial" artinya bahwa tenaga kerja rumahtangga tidak hanya menggantungkan pada peluang kerja yang ada di daerahnya, melainkan bermigrasi hingga ke luar daerah, dengan kata lain terbatasnya peluang sumber nafkah yang ada di kampung setempat, mendorong tenaga kerja rumahtangga melakukan mobilitas spasial.

2. "Pola nafkah ganda"; yaitu mengkombinasikan aktifitas nafkah pertanian dan non-pertanian sekaligus dalam jangka waktu yang lama atau hampir permanen (livelihood diversification atau multiple employment). Pola nafkah ganda terutama dilakukan oleh rumahtangga petani transmigran di Kampung Sumberboga, dan mulai tampak sedikit menonjol di Kampung Meiforgah dan Sembab.

3. "Pola nafkah berbasis bantuan"; yaitu nafkah yang bersumberkan pada bantuan karitatif dari pemerintah ataupun kerabat. Sumber bantuan bagi rumahtangga petani asli di Kampung Sembab dan petani transmigran Kampung Meiforgah biasanya diperoleh dari program BLT (bantuan langsung tunai), Raskin (beras untuk rakyat miskin), bantuan bahan bangunan, beasiswa pendidikan dan lainlain. Menarik untuk dicatat bahwa penerima bantuan, kebanyakan adalah rumahtangga petani dari etnis Papua. Sementara rumahtangga petani etnis Jawa, cenderung lebih memilih usaha mandiri dan menghindarkan diri dari program bantuan.

Fakta di lapangan juga memperlihatkan bahwa, rumahtangga petani transmigran yang menggandakan sumber nafkahnya (livelihood diversification) terlihat tampak lebih progresif dibandingkan yang bersumber nafkah relatif tunggal. Desa dengan rumahtangga bersumber nafkah ganda tampak jauh lebih makmur secara ekonomi dibandingkan yang lainnya.

\section{STRUKTUR NAFKAH NON PERTANIAN DAN PELAPISAN SOSIAL}

Studi juga mengidentifikasi bahwa kebanyakan rumahtangga petani transmigran yang menggandakan sumber nafkahnya (di Kampung Sumberboga) tidak hanya terbatas pada satu lapisan sosial saja. Gambar 2 memperlihatkan bahwa semua lapisan sosial terlibat dalam nafkah atau pekerjaan produktif pertanian dan non pertanian (non farm).

Rumahtangga petani transmigran etnis Jawa yang tinggal di Kampung Sumberboga memiliki ragam ekonomi nafkah yang jauh lebih tinggi daripada rumahtangga petani dari etnis asli Papua yang berada di Kampung Meiforgah dan Sembab. Aktivitasaktivitas nafkah di sektor non-farm jauh lebih berkembang dibanding sektor farm itu 
sendiri. Ada dinamika yang menarik untuk disebutkan disini. Pada masa awal rumahtangga transmigran memulai kehidupannya (di masa lalu), sektor pertanian menjadi basis nafkah yang penting. Namun, dengan keuletan dan semangat kemandirian yang dimiliki oleh rumahtangga transmigran asal Jawa, mereka berhasil mengembangkan kegiatan-kegiatan ekonomi di luar pertanian yang menguntungkan. Dengan upaya ini, maka perekonomian wilayah setempat bergerak lebih cepat. Sedangkan di rumahtangga petani transmigran di Meiforgah dan Sembab masih lebih banyak mengandalkan kehidupan ekonomi rumahtangganya dari sektor pertanian, sekalipun non-farm mulai agak berkembang (lihat Gambar 2; Gambar 3; Gambar 4).

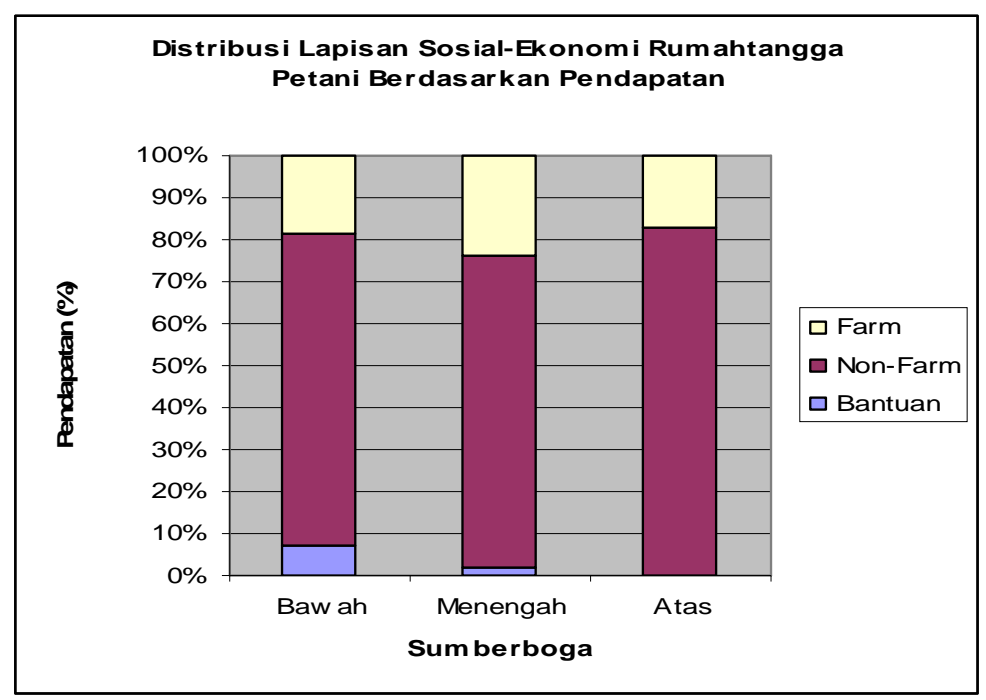

Sumber: data primer (diolah)

Gambar 2. Lapisan Sosial dan Nafkah (Sumber Pendapatannya) di Kampung Sumberboga, 2008

Sekalipun tidak seintensif Kampung Sumberboga, namun proses transformasi struktur nafkah rumahtangga petani transmigran di Meiforgah berjalan cukup menarik. Di kawasan itu, hanya lapisan menengah dan atas saja yang mulai bergiat di sektor non pertanian. Secara umum, ekonomi bantuan (karitatif) menyumbang porsi cukup besar dalam struktur nafkah di Meiforgah.

Keadaan di Kampung Sembab sebagai kawasan kontrol yang didiami oleh rumahtangga petani asli papua, menunjukkan gejala yang sama (sekalipun tidak nyata) dengan rumahtangga petani transmigran Meiforgah (Gambar 4).

Dari Gambar 3 dan 4 di atas, disimpulkan bahwa semakin tinggi status ekonomi rumahtangga petani di Meiforgah dan Sembab, maka makin beragam pula sumber nafkahnya. Artinya makin tinggi lapisan ekonomi rumahtangga petani di Meiforgah dan Sembab maka makin intensif pula persentuhannya dengan sektor non-farm. Hanya rumahtangga petani skala kecil yang tetap berada di sektor pertanian dan tidak dapat menentukan pilihan apapun untuk keluar dari sektor pertanian. Sekalipun demikian, perlu dicatat bahwa persentuhan atau derajat intensitas 
keterlibatan rumahtangga petani di Meiforgah dan Sembab dengan sektor non-farm relatif sangat kecil bila dibandingkan dengan mereka dari Sumberboga.

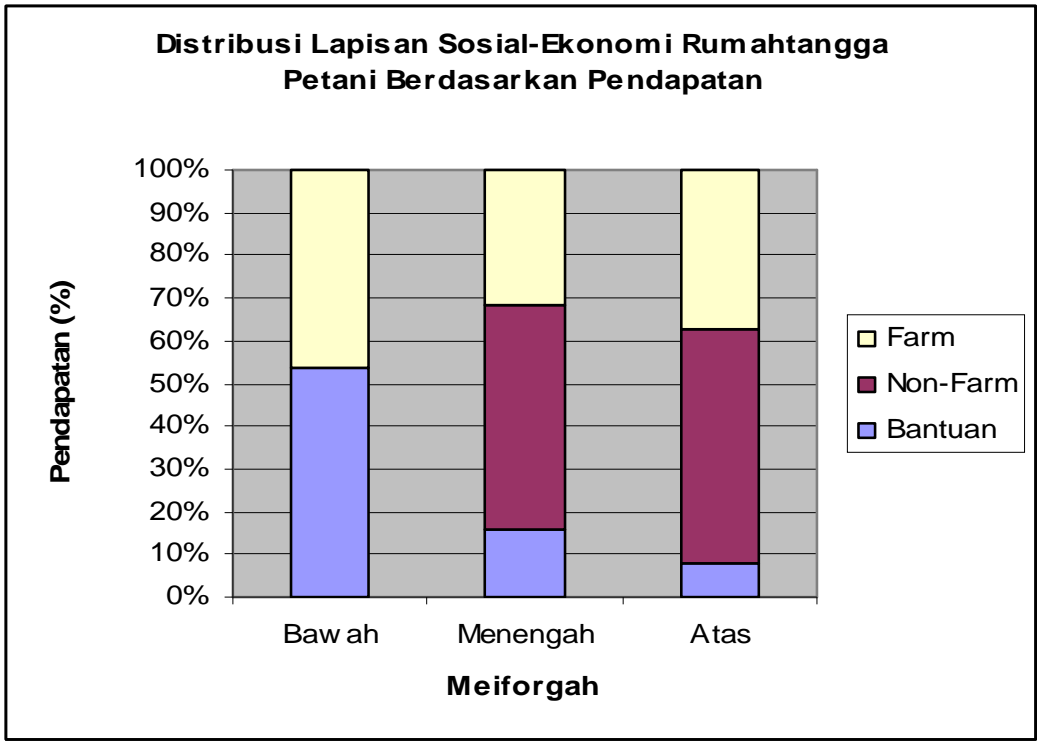

Sumber: data primer (diolah)

Gambar 3. Lapisan Sosial dan Nafkah (Sumber Pendapatannya) di

Kampung Meiforgah, 2008

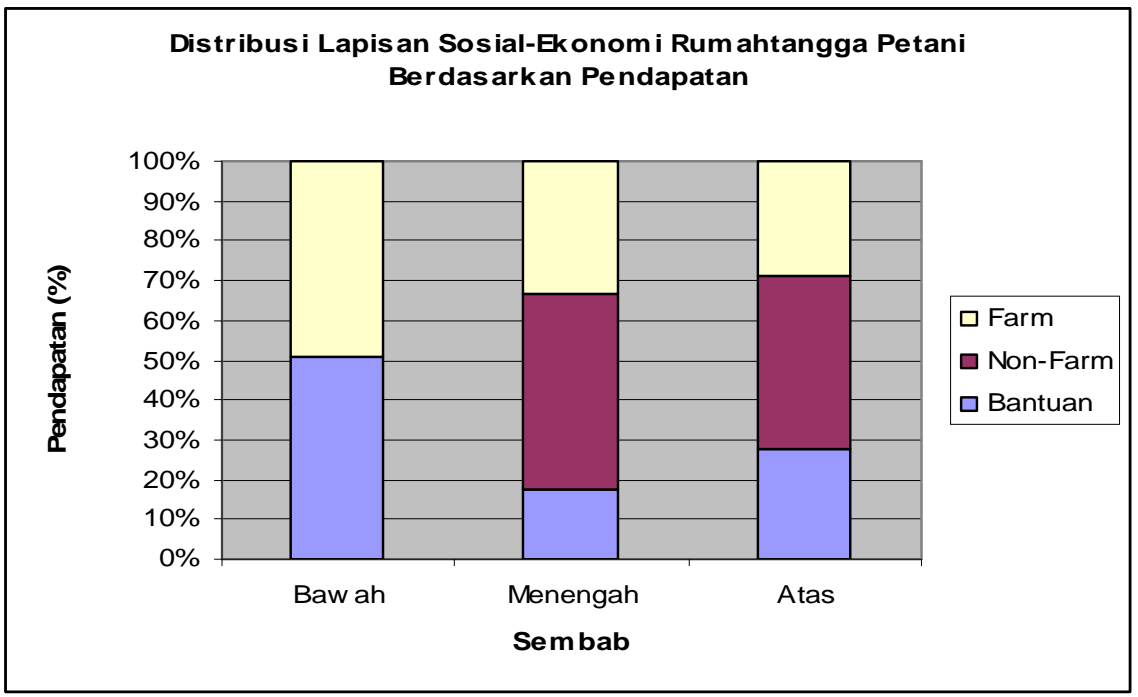

Gambar 4. Lapisan Sosial dan Nafkah (Sumber Pendapatannya) di Kampung Sembab, 2008 
Tabel 3. Derajat Keterlibatan Rumahtangga di Sektor Non Pertanian (Non Farm) Menurut Lapisan dan Tingkat Pendapatan (x Rp 000/tahun), tahun 2008

\begin{tabular}{|c|c|c|c|c|c|c|c|c|c|c|}
\hline \multirow[t]{2}{*}{ No } & \multirow[t]{2}{*}{ Kampung } & \multicolumn{3}{|c|}{ Lapisan Bawah } & \multicolumn{3}{|c|}{ Lapisan Menengah } & \multicolumn{3}{|c|}{ Lapisan Atas } \\
\hline & & Farm & $\begin{array}{l}\text { Non- } \\
\text { farm }\end{array}$ & $\begin{array}{l}\text { Ban- } \\
\text { tuan }\end{array}$ & Farm & $\begin{array}{l}\text { Non- } \\
\text { farm }\end{array}$ & $\begin{array}{l}\text { Ban- } \\
\text { tuan }\end{array}$ & Farm & $\begin{array}{l}\text { Non- } \\
\text { farm }\end{array}$ & $\begin{array}{l}\text { Ban- } \\
\text { tuan }\end{array}$ \\
\hline 1 & Sumberboga & $\begin{array}{l}4.100 \\
(19 \%)\end{array}$ & $\begin{array}{l}16.208 \\
(74 \%)\end{array}$ & $\begin{array}{l}1.600 \\
(7 \%)\end{array}$ & $\begin{array}{l}7.200 \\
(24 \%)\end{array}$ & $\begin{array}{l}22.347 \\
(74 \%)\end{array}$ & $\begin{array}{l}6.400 \\
(2 \%)\end{array}$ & $\begin{array}{l}7.000 \\
(17 \%)\end{array}$ & $\begin{array}{l}24.031 \\
(83 \%)\end{array}$ & $\begin{array}{l}0 \\
(0 \%)\end{array}$ \\
\hline 2 & Meiforgah & $\begin{array}{l}6.260 \\
(47 \%)\end{array}$ & $\begin{array}{l}0 \\
(0 \%)\end{array}$ & $\begin{array}{l}7.190 \\
(53 \%)\end{array}$ & $\begin{array}{l}6.360 \\
(31 \%)\end{array}$ & $\begin{array}{l}10.713 . \\
(53 \%)\end{array}$ & $\begin{array}{l}3.200 \\
(16 \%)\end{array}$ & $\begin{array}{l}8.000 \\
(37 \%)\end{array}$ & $\begin{array}{l}11.833 \\
(55 \%)\end{array}$ & $\begin{array}{l}1.690 \\
(8 \%)\end{array}$ \\
\hline 3 & Sembab & $\begin{array}{l}6.661 \\
(49 \%)\end{array}$ & $\begin{array}{l}0 \\
(0 \%)\end{array}$ & $\begin{array}{l}6.875 \\
(51 \%)\end{array}$ & $\begin{array}{l}7.280 \\
(33 \%)\end{array}$ & $\begin{array}{l}10.713 . \\
(49 \%)\end{array}$ & $\begin{array}{l}3.833 \\
(18 \%)\end{array}$ & $\begin{array}{l}7.600 \\
(29 \%)\end{array}$ & $\begin{array}{l}11.250 \\
(43 \%)\end{array}$ & $\begin{array}{l}7.304 \\
(28 \%)\end{array}$ \\
\hline
\end{tabular}

Sumber: data primer (diolah)

\section{TRANSFORMASI STRUKTUR NAFKAH DAN KETIMPANGAN SOSIAL}

Analisis ini hendak melihat apakah keterlibatan rumahtangga petani pada sumber nafkah non-farm (yang menyumbang kontribusi signifikan terhadap total pendapatan rumahtangga) mengakibatkan ketimpangan antar lapisan? Analisis terhadap indeks Gini pada Tabel 4 memperlihatkan bahwa untuk Kampung Sumberboga angkanya adalah 0,17. Bila angka tersebut dibandingkan dengan Meiforgah $(0,073)$ dan Sembab (),058), maka hal ini sangat nyata mengindikasikan adanya ketimpangan sosial yang berarti di Sumberboga. Tidak dapat dielakkan lagi, bahwa penguatan sektor non-farm telah menyebabkan ketimpangan/kesenjangan pendapatan antar lapisan rumahtangga petani yang cukup tinggi di Kampung Sumberboga.

Tabel 4 . Disparitas Tingkat Pendapatan Antar Lapisan di Tiga Kampung Studi, 2008

\begin{tabular}{|c|l|c|}
\hline No & \multicolumn{1}{|c|}{ Kampung } & Indeks Gini \\
\hline 1 & Sumberboga & 0,170 \\
\hline 2 & Meiforgah & 0,073 \\
\hline 3 & Sembab & 0,058 \\
\hline
\end{tabular}

Sumber: data primer (diolah)

Sementara itu, karena ketergantungan rumahtangga petani yang merata pada sektor pertanian di dua kampung yang lain, maka perbedaan tingkat pendapatan tidak mencolok di kampung-kampung tersebut. Dengan demikian, meskipun sumber nafkah non-farm telah berhasil mendorong pertumbuhan ekonomi yang cukup baik, namun kehadirannya memberikan dampak pada ketimpangan sosial yang sangat berarti.

\section{STRUKTUR PENGELUARAN DAN KAPASITAS MENABUNG}

Apabila kapasitas menabung (saving capacity) rumahtangga petani dalam derajat yang tinggi, maka hal ini akan memberikan peluang bagi kawasan untuk berkembang lebih maju. Dari data diperoleh fakta bahwa, sektor non-farm memberikan peluang bagi rumahtangga petani untuk meningkatkan kapasitas menabung mereka.

Seterusnya, perkembangan sektor non-farm mendorong investasi di kawasan tersebut makin kondusif. Dengan demikian, pertumbuhan ekonomi kawasan 
terdorong naik, meskipun disertai dengan "biaya sosial" yang muncul berupa ketimpangan sosial antar lapisan yang makin nyata. Secara umum, rumahtangga petani dari lapisan sosial atas yang tinggi kapasitas menabungnya.

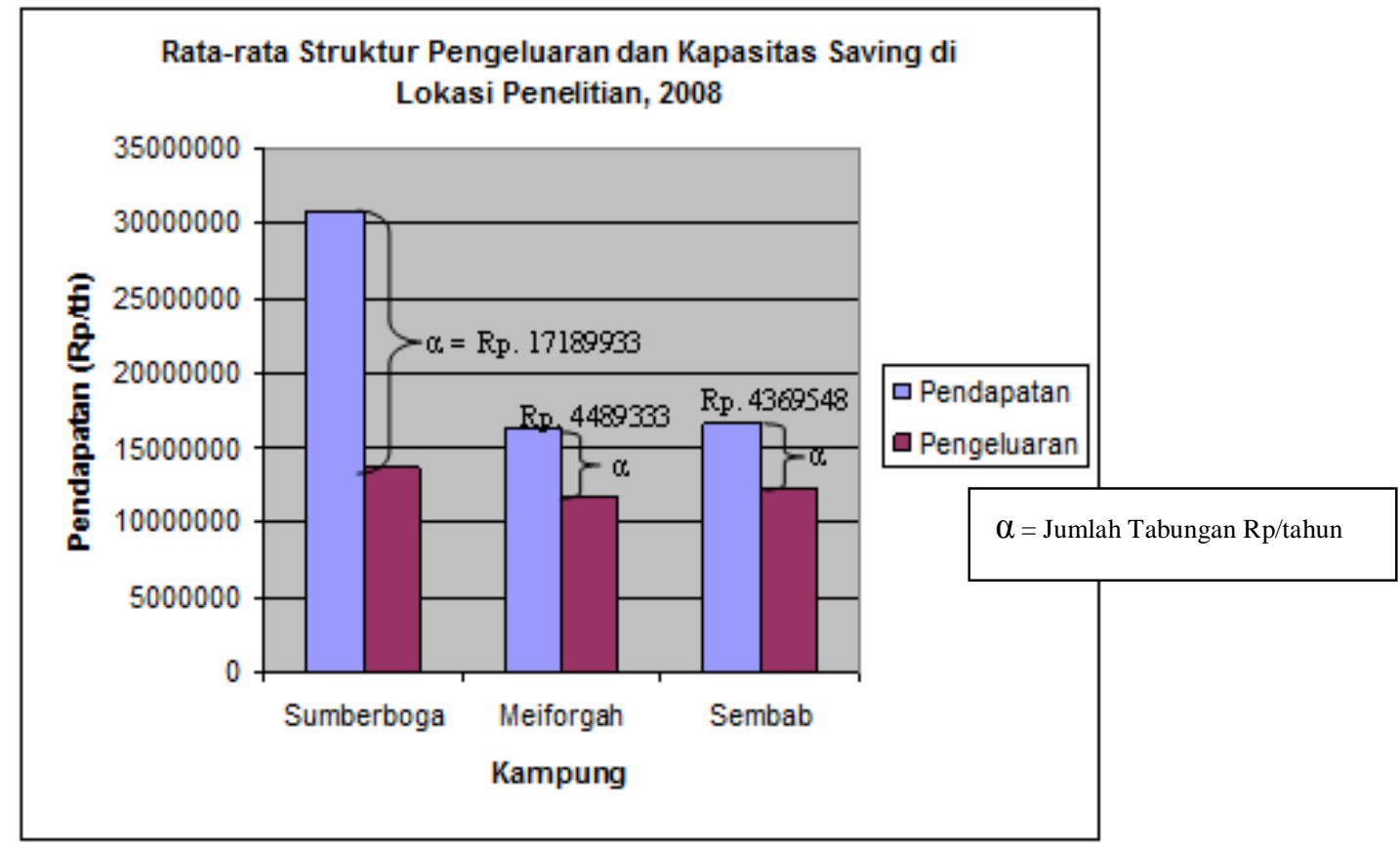

Sumber: data primer (diolah)

Gambar 3. Struktur Pengeluaran dan Kapasitas Menabung Rumahtangga Petani di Tiga Kampung, 2008

\section{ARAHAN PENGEMBANGAN WILAYAH}

Skenario program jangka pendek. Secara jangka pendek, bila pertanian tetap akan dipertahankan keberadaannya, maka sektor tersebut perlu terus diperkuat di tingkat rumahtangga. Upaya dilakukan melalui pengenalan terhadap usaha tani yang intensif. Artinya, tidak lagi mempraktekkan pertanian ekstensif yang berproduktivitas rendah dan melelahkan bagi petani asli Papua. Dalam waktu yang bersamaan, perkuatan ekonomi rumahtangga di sektor non-pertanian (non-farm) perlu terus dilakukan sebagai penghela pertumbuhan ekonomi rumahtangga.

Pengembangan diversifikasi pangan via diversifikasi nafkah. Bila nafkah atau livelihood dimaknai secara lebih sempit sebagai "pengamanan pangan", maka upaya menguatkan ketahanan ekonomi rumahtangga berarti juga sebagai upaya memperkuat ketahanan pangan. Program jangka panjang yang ditempuh dalam hal ini, melalui skenario pengembangan diversifikasi nafkah. Penguatan struktur nafkah berbasiskan baik di sektor farm maupun non farm.

Pergeseran paragdima pengembangan wilayah di Papua Barat. Diperlukan suatu kesadaran baru untuk "keluar" dari carapandang lama bahwa pembangunan pedesaan harus selalu bertumpu hanya pada sektor pertanian. Dengan carapandang yang baru, sektor non pertanian mendapat tempat yang seimbang dibandingkan 
sektor pertanian. Program pengembangan sektor non pertanian (non-farm) sepantasnya disusun secara lebih terencana untuk menggerakkan ekonomi kawasan. Sektor non pertanian yang dapat dikembangkan pada tahap awal, misalnya industri pengolah hasil pertanian, perdagangan pertanian ataupun jasa-jasa penopang pertanian.

\section{Dimensi ekonomi politik pengembangan kawasan di Papua Barat.} Pengembangan kawasan dengan mengkombinasikan sumber nafkah pertanian dan non pertanian memberikan sebuah resiko yang tidak dapat dielakkan. Resiko tersebut adalah: terbukanya perekonomian lokal ke sistem ekonomi eksternal yang memberikan beberapa implikasi-implikasi yang kurang nyaman bagi masyarakat lokal. Implikasi lanjutan tersebut adalah ketergantungan, ketimpangan antar daerah, kompetisi, konflik, dan marjinalisasi sosial bagi rumahtangga yang tidak mampu berkompetisi dan menyesuaikan pada kekuatan-kekuatan eksternal. Disparitas sosial antar rumahtangga juga meningkat. Hal ini berpotensi pada perbedaan status sosial yang tinggi dan memicu konflik.

Model pengembangan wilayah di Papua Barat. Pelajaran dari tiga kampung penelitian di Papua Barat secara singkat mengarahkan pemikiran, bahwa Sumberboga adalah potret keberhasilan pertumbuhan ekonomi kawasan transmigran yang diinisiasi dan didukung oleh etika kerja petani beretnis Jawa. Pertumbuhan ekonomi yang tinggi sekilas menggembirakan, namun dalam jangka panjang menggerus solidaritas sosial, keharmonisan kehidupan sosial dalam kesamaan kolektivitas dan persudaraan. Sementara itu Meforgah dan Sembab mewakili kampung-kampung tradisi yang "masih cukup harmonis" (perbedaan-perbedaan kehidupan sosialnya masih tidak kentara), karena belum mengalami pertumbuhan ekonomi kawasan yang tinggi dari berkembangnya non-farm. Bila pertumbuhan kesejahteraan merupakan cita-cita umum, maka ke depan perlu dorongan untuk mendiversifikasikan nafkah di tingkat rumahtangga, namun disertai pengendalian kehidupan sosial yang seimbang agar keharmonisan tradisi tetap terjaga.

\section{KESIMPULAN DAN SARAN}

Karakter sosio-budaya rumahtangga transmigran terbukti sangat mempengaruhi sejauhmana pencapaian tingkat kesejahteraan ekonomi, yang diukur dari tingkat pendapatan rumahtangga. Rumahtangga petani etnis Jawa memiliki tingkat pendapatan yang jauh lebih tinggi dibandingkan rumahtangga petani etnis asli Papua, karena perbedaan carapandang dalam merespons tantangan ekonomi di kawasan tersebut. Dalam hal ini kehadiran sektor non-farm memberikan pengaruh kuat terjadinya transformasi sosial-ekonomi di kawasan studi. Selain mendorong perekonomian, memberikan kontribusi pada kapasitas menabung, sektor non-farm juga menyebabkan dampak kurang diharapkan berupa disparitas derajat kesejahteraan ekonomi yang sangat mencolok.

Arah pengembangan kawasan di tiga kampung (desa) transmigran berdasarkan hasil penelitian ini, dikembangkan dengan strategi sebagai berikut: (a). Kampung dengan tipe Sumberboga dikembangkan dengan berbasiskan/bertumpu pada ekonomi non farm dan farm secara sekaligus dan saling memperkuat, dan (b). Kampung dengan tipe Sembab dan Meiforgah dikembangkan dengan berbasiskan pada pertanian namun secara perlahan dilakukan penguatan sektor non pertaniannya. Disarankan bahwa untuk mengimbangi pertumbuhan ekonomi yang diciptakan oleh non farm, 
maka proses-proses transformasi sosial yang berjalan di tingkat komunitas kampung (akibat non farm activities) perlu disertai dengan upaya pemupukan modal sosial terus-menerus agar disparitas sosio-ekonomi yang terbentuk tidak memberikan dampak negatif pada keseluruhan sistem sosio-ekonomi di kawasan setempat.

\section{DAFTAR PUSTAKA}

Alderman, H. and Garcia, M. 1993. Poverty, household food security, and nutrition in rural Pakistan. Research Report 96. International Food Policy Research Institute: Washington, D.C.

BPS Manokwari. 2007. Kabupaten Manokwari dalam Angka 2007. Badan Pusat Statistik: Manokwari.

Dharmawan, A. H. 2000. Farm Household Livelihood Strategies and SocioEconomic Changes in Rural Indonesia. Disertasi. University of Goettingen: Jerman.

Dharmawan, A. H. 2002. Pengembangan Komunitas dan Pedesaan Berkelanjutan. Tajukan Modul SEP-51E. Magister Profesional Pengembangan Masyarakat. Jurusan Ilmu-Ilmu Sosial Ekonomi. Fakultas Pertanian. Institut Pertanian Bogor: Bogor.

Dharmawan, A. H. 2007. Sistem Penghidupan dan Nafkah Pedesaan: Pandangan Sosiologi Nafkah (Livelihood Sociology) Mazhab Barat dan Mazhab Bogor. Sodality: Jurnal Transdisiplin Sosiologi, Komunikasi dan Ekologi Manusia. Vol. 01/02, pp. 169-192.

Direktorat Jenderal Pembinaan Pengembangan Masyarakat dan Kawasan Transmigrasi, 2006. Kota Terpadu Mandiri. Departemen Tenaga Kerja dan Transmigrasi: Jakarta.

Iqbal, M. 2004. Strategi Nafkah Rumahtangga Nelayan; Studi Kasus di Dua Desa Nelayan Kabupaten Lamongan Jawa Timur. Tesis Master Program Studi Sosiologi Pedesaan. Institut Pertanian Bogor: Bogor.

Juanda, B. 2007. Metodologi Penelitian Ekonomi dan Bisnis. Institut Pertanian Bogor Press: Bogor.

Khairuddin, 1992. Pembangunan Masyarakat. Penerbit Liberty: Yogyakarta.

Mardiyaningsih, D. I. 2003. Industri Pariwisata dan Dampaknya terhadap Kehidupan Sosial-Ekonomi Masyarakat Lokal ; Kasus Dua Desa di Kecamatan Borobudur, Kabupaten Magelang. Propinsi Jawa Tengah. Skripsi Jurusan Sosek Pertanian. Institut Pertanian Bogor: Bogor.

Mizra, R. P. 1982. Regional Development. Mauruzen Investment, Ltd: Singapore.

Nurmalinda. 2002. Petani Miskin di Pinggiran Perkotaan dan Strategi Bertahan Hidup Rumah Tangga; Studi Kasus Petani Lahan Tidur di Kab. Bekasi. Tesis Master Program Studi Sosiologi Pedesaan. IPB.

Priyono. 2004. Penetapan Kriteria Wilayah Pengembangan Transmigrasi (WPT), Lokasi Pemukiman Transmigrasi (LPT) dan Kawasan Transmigrasi. 
Pusat Penelitian dan Pengembangan Ketransmigrasian. Departemen Tenaga Kerja dan Transmigrasi: Jakarta.

Ramadhan K. H. et. al. 1993. Transmigrasi Harapan dan Tantangan. Departemen Transmigrasi: Jakarta.

Scoones, I. 1998. Sustainable Rural Livelihood : A Framework for Analysis. Institute of Development Studies: Sussex. UK

Suwartika. R, 2003. Modal Usaha dan Fungsi Modal Sosial dalam Strategi Bertahan Hidup Pekerja Migran di Sektor Informal, Skripsi Sosek. Faperta Institut Pertanian Bogor: Bogor.

Utomo, M. 2005. Tinjauan Kritis Kebijakan dan Implementasi Penyelenggaraan Transmigrasi. Makalah disampaikan pada Semiloka "Transmigrasi dan Penguatan NKRI" DPP Partai Golkar Korbid Nakertrans, 30 Nopember 2005. Jakarta. 